OPEN ACCESS

Edited by:

Alexandre Morrot

Universidade Federal do Rio de

Janeiro, Brazil

Reviewed by:

Debora Decote-Ricardo,

Universidade Federal Rural do Rio de

Janeiro, Brazi

Mario M. D'Elios,

University of Florence, Italy

*Correspondence:

Alexis Kaushansky

alexis.kaushansky@cidresearch.org

Specialty section:

This article was submitted to

Microbial Immunology,

a section of the journal

Frontiers in Microbiology

Received: 10 September 2017

Accepted: 24 October 2017

Published: 16 November 2017

Citation:

Zuck M, Austin LS, Danziger SA

Aitchison JD and Kaushansky A (2017) The Promise of Systems

Biology Approaches for Revealing Host Pathogen Interactions in Malaria.

Front. Microbiol. 8:2183.

doi: 10.3389/fmicb.2017.02183

\section{The Promise of Systems Biology Approaches for Revealing Host Pathogen Interactions in Malaria}

\author{
Meghan Zuck ${ }^{1}$, Laura S. Austin ${ }^{1}$, Samuel A. Danziger ${ }^{1,2}$, John D. Aitchison ${ }^{1,2}$ and \\ Alexis Kaushansky ${ }^{1,3 *}$ \\ ${ }^{1}$ Center for Infectious Disease Research, formerly Seattle Biomedical Research Institute, Seattle, WA, United States, \\ ${ }^{2}$ Institute for Systems Biology, Seattle, WA, United States, ${ }^{3}$ Department of Global Health, University of Washington, Seattle, \\ WA, United States
}

Despite global eradication efforts over the past century, malaria remains a devastating public health burden, causing almost half a million deaths annually (WHO, 2016). A detailed understanding of the mechanisms that control malaria infection has been hindered by technical challenges of studying a complex parasite life cycle in multiple hosts. While many interventions targeting the parasite have been implemented, the complex biology of Plasmodium poses a major challenge, and must be addressed to enable eradication. New approaches for elucidating key host-parasite interactions, and predicting how the parasite will respond in a variety of biological settings, could dramatically enhance the efficacy and longevity of intervention strategies. The field of systems biology has developed methodologies and principles that are well poised to meet these challenges. In this review, we focus our attention on the Liver Stage of the Plasmodium lifecycle and issue a "call to arms" for using systems biology approaches to forge a new era in malaria research. These approaches will reveal insights into the complex interplay between host and pathogen, and could ultimately lead to novel intervention strategies that contribute to malaria eradication.

Keywords: malaria, plasmodium, liver, systems biology, computational modeling, omics-technologies

\section{INTRODUCTION}

Parasitic diseases infect over half a billion people worldwide, and are a tremendous public health burden. Malaria is the most lethal, causing infection and death primarily in young children in sub Saharan Africa (WHO, 2016). In humans, five Plasmodium species are known to cause disease, with the greatest burden arising from infection with $P$. falciparum and P. vivax. Despite multifaceted control efforts, the adaptive nature of the Plasmodium parasite has confounded vaccine development (Neafsey et al., 2015; Schats et al., 2015), and has contributed to the emergence of widespread drug resistance (reviewed in Blasco et al., 2017).

The life cycle of Plasmodium is complex. The parasite cycles between mosquito and mammalian hosts, with elaborate developmental and differentiation processes within each. Every transition represents an opportunity to arrest the parasite, and to stop subsequent life cycle progression. A systematic approach that identifies key components required by the parasite at each stage of its life cycle could ultimately elucidate fundamental pathogenesis strategies, which will 
aid the development of cohesive intervention approaches. By contrast, any approach that reduces the biology of the parasite to a single antigen or drug target leaves open the possibility of parasite adaptation and, ultimately, intervention failure. Here, we propose a systems biology approach to interrogate the Plasmodium parasite that, although not without its challenges, will result in a global view of the host-parasite interactions during key transition states in the life cycle. This view could inform interventions that are not easily circumvented by the parasite and therefore contribute to malaria eradication.

\section{PLASMODIUM PARASITES HAVE A COMPLEX LIFE CYCLE THAT ENGAGES MULTIPLE HOST ENVIRONMENTS}

Plasmodium infection of mammals begins with injection of the sporozoite into the skin of the vertebrate host during the bite of a female Anopheles mosquito. After migration through the skin and entrance into a capillary, sporozoites travel through the blood stream to the liver. The parasite then traverses through the sinusoidal barrier to gain access to hepatocytes (Mota et al., 2001; Ishino et al., 2004; Tavares et al., 2013; Cha et al., 2016; Yang et al., 2017). Once within the liver parenchyma, sporozoites infect a host hepatocyte within which they will reside for the next 2-10 days (reviewed in Kaushansky and Kappe, 2015b; Vaughan and Kappe, 2017). Following liver stage development, parasites exit the liver, re-enter the blood stream and infect erythrocytes. During asexual blood stage infection, parasites undergo cycles of replication, followed by destruction of the host cell. It is this cycle that causes disease symptoms.

During the blood stage, a portion of parasites commit to sexual development (Coleman et al., 2014; Kafsack et al., 2014; Sinha et al., 2014; Poran et al., 2017) and initiate a differentiation process that occurs largely in the bone marrow (Joice et al., 2014). Once female and male forms have nearly completed maturation, they re-enter the blood stream and are transmitted to mosquitoes. In the mosquito midgut, fertilization occurs, generating a motile diploid (ookinete), which then replicates its DNA and develops into a stationary oocyst. Sporozoites then form within the midgut oocyst, become motile, and travel to the salivary glands. Once within the salivary glands, the parasite is transmitted to the next mammalian host during a blood meal. Each of these stage transitions is initiated by, and induces, broad, systematic changes that alter cellular behaviors (Table 1, Figure 1). Yet, these changes cannot be fully represented by any single transcript or individual cellular measurement. Rather, comprehensive changes within interconnected networks occur on multiple scales. This includes changes in gene regulatory networks, protein interactions with other biomolecules, and morphological variation of host and parasite subcellular structures. Together, these changes drive stage transitions. The goal must therefore be to establish a comprehensive picture of the host and parasite effector molecules and networks that are required to facilitate life cycle transitions.
TABLE 1 | Stage transitions in the Plasmodium life cycle.

\begin{tabular}{|c|c|c|}
\hline $\begin{array}{l}\text { Life cycle stage } \\
\text { transition }\end{array}$ & $\begin{array}{l}\text { System-level } \\
\text { alteration reported }\end{array}$ & References \\
\hline $\begin{array}{l}\text { Development from midgut } \\
\text { sporozoite to salivary } \\
\text { gland sporozoite }\end{array}$ & $\begin{array}{l}\text { Transcriptome } \\
\text { changes }\end{array}$ & $\begin{array}{l}\text { Matuschewski et al., } \\
2002 \text {; Mikolajczak et al., } \\
2008\end{array}$ \\
\hline $\begin{array}{l}\text { Transmission between } \\
\text { mosquito and mammalian } \\
\text { host }\end{array}$ & $\begin{array}{l}\text { Translational } \\
\text { repression }\end{array}$ & $\begin{array}{l}\text { Zhang et al., 2010; } \\
\text { Gomes-Santos et al., } \\
\text { 2011; Muller et al., 2011; } \\
\text { Lindner et al., 2013; } \\
\text { Silvie et al., 2014; Silva } \\
\text { et al., } 2016\end{array}$ \\
\hline $\begin{array}{l}\text { Development through } \\
\text { Liver Stage }\end{array}$ & $\begin{array}{l}\text { Transcriptome and } \\
\text { proteome changes }\end{array}$ & $\begin{array}{l}\text { Tarun et al., 2008; } \\
\text { Albuquerque et al., 2009; } \\
\text { Vaughan et al., } 2009\end{array}$ \\
\hline $\begin{array}{l}\text { Exit from Liver Stage and } \\
\text { Entry into Blood Stage }\end{array}$ & $\begin{array}{l}\text { Transcriptome } \\
\text { changes }\end{array}$ & Tarun et al., 2008 \\
\hline $\begin{array}{l}\text { Differentiation into sexual } \\
\text { forms }\end{array}$ & $\begin{array}{l}\text { Epigenetic and } \\
\text { Transcriptome } \\
\text { changes }\end{array}$ & $\begin{array}{l}\text { Coleman et al., 2014; } \\
\text { Kafsack et al., 2014; } \\
\text { Sinha et al., 2014; Poran } \\
\text { et al., } 2017\end{array}$ \\
\hline $\begin{array}{l}\text { Transmission from } \\
\text { mammalian to mosquito } \\
\text { host }\end{array}$ & $\begin{array}{l}\text { Translational } \\
\text { repression }\end{array}$ & $\begin{array}{l}\text { Mair et al., 2006; } \\
\text { Guerreiro et al., 2014; } \\
\text { Lasonder et al., } 2016\end{array}$ \\
\hline $\begin{array}{l}\text { Gametocyte to gamete } \\
\text { transformation }\end{array}$ & Proteome changes & Khan et al., 2005 \\
\hline
\end{tabular}

\section{PLASMODIUM PARASITES SIGNIFICANTLY ALTER THE BIOLOGY OF THEIR HOSTS}

To illustrate the need to comprehensively evaluate changes during the Plasmodium life cycle, we will consider one stage of the complex life cycle of the parasite in detail-the Liver Stage of infection. Once within the liver sinusoid, the parasite traverses through phagocytic Kupffer cells, liver-resident macrophages, and liver endothelial sinusoidal cells, to access hepatocytes, while avoiding phagocytosis (Mota et al., 2001; Ishino et al., 2004; Usynin et al., 2007; Tavares et al., 2013; Cha et al., 2016; Yang et al., 2017). Once in the liver parenchyma, the parasite continues to traverse through several hepatocytes before selecting a suitable host for invasion. While the precise properties that make one hepatocyte more hospitable than another remain unknown, altered levels of specific hepatocyte receptors dramatically alter infection rates (Silvie et al., 2003; Ishino et al., 2004; Rodrigues et al., 2008; Yalaoui et al., 2008a; Kaushansky et al., 2015).

Following establishment of an intracellular niche within the hepatocyte, Plasmodium replicates extensively, stretching the hepatocyte to 50-100 times its normal volume (Shortt and Garnham, 1948; Vaughan et al., 2012). This rapid expansion is surprising, given the cell's strict cell size regulations under normal conditions (Sinturel et al., 2017). This observation suggests that Plasmodium effectively overwrites the hepatocyte's hardwiring to exert massive influence over the host cell. Plasmodium likely disrupts a multitude of classical signaling pathways during infection, only a small 
A

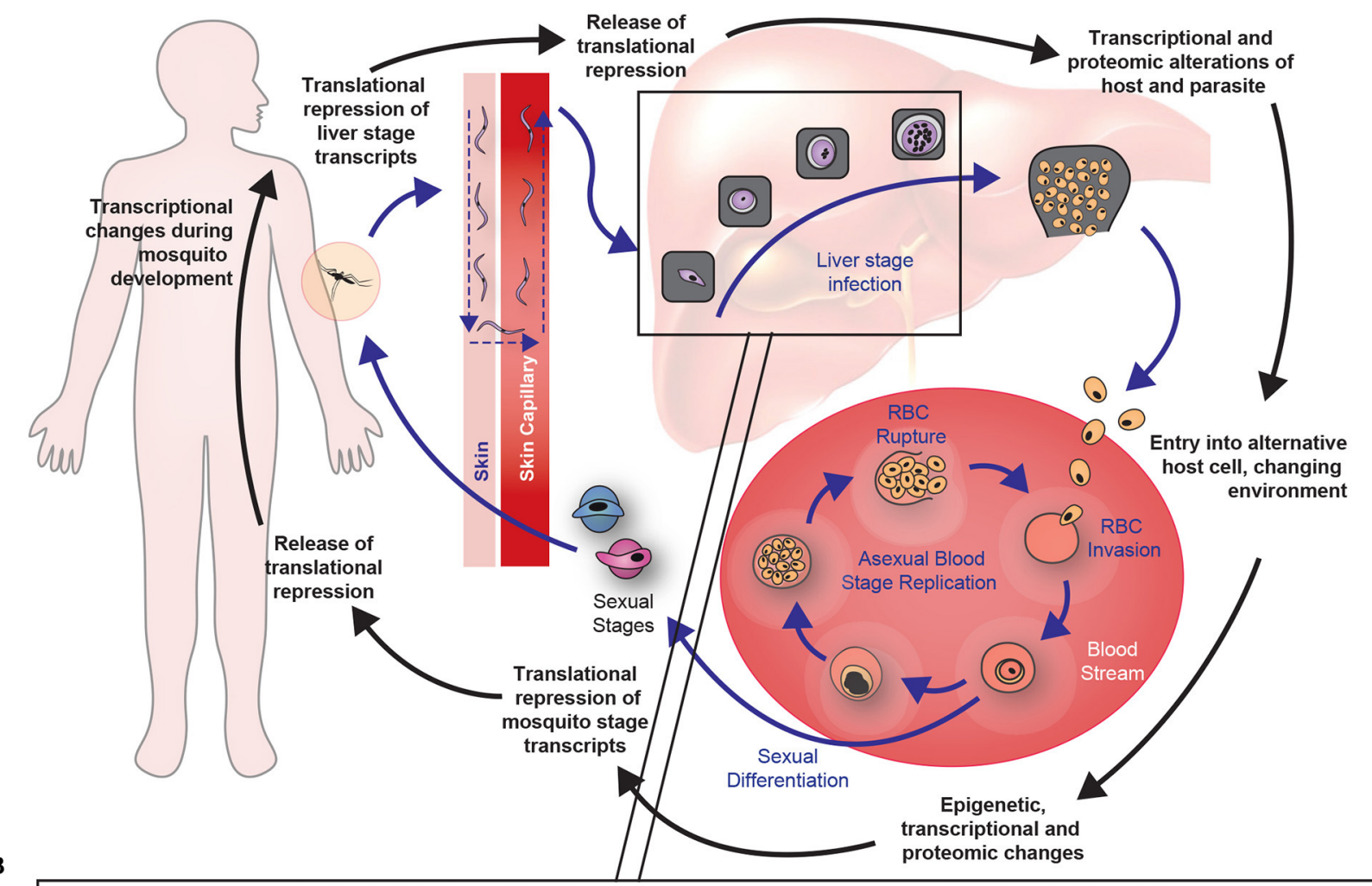

B

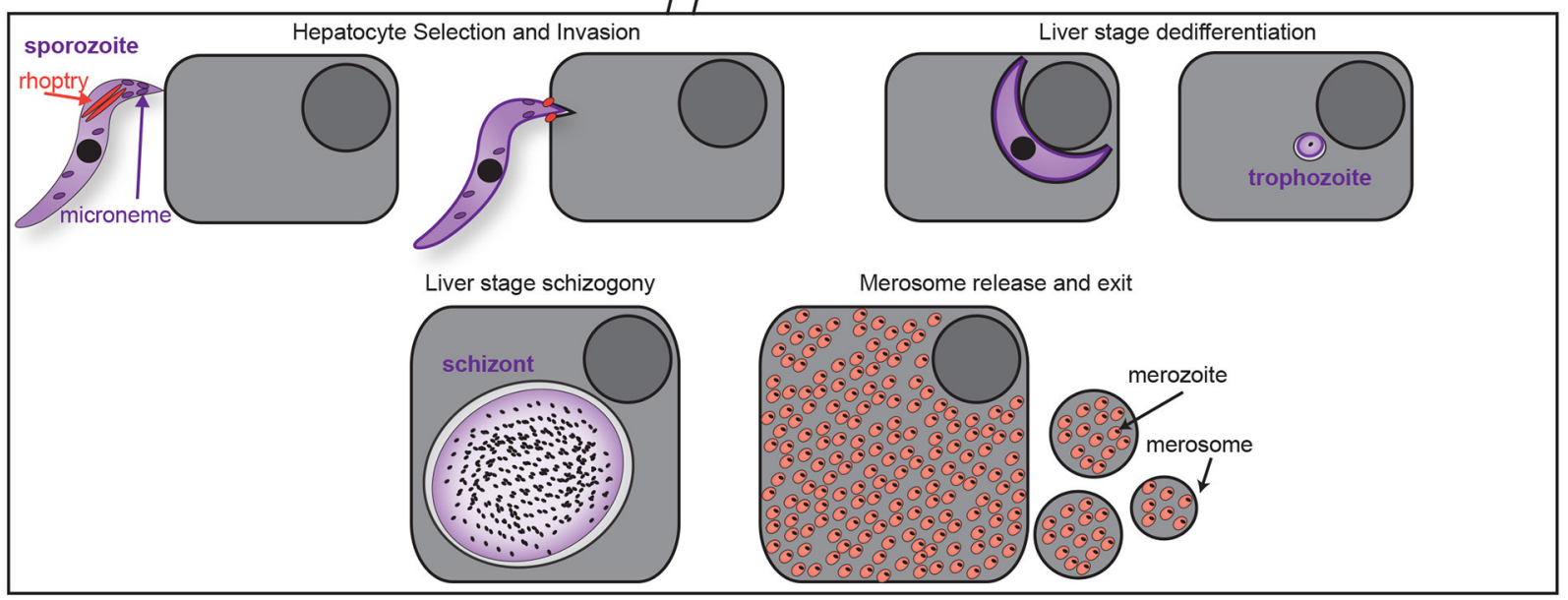

FIGURE 1 | Plasmodium life cycle. (A) Each stage of the malaria life cycle is accompanied by unique transcriptional or translational changes, which ultimately allow for successful transition to each stage of the life cycle. Red Blood Cell is abbreviated "RBC." (B) Liver stage infection of a hepatocyte is a unique microenvironment that allows the parasite to invad and differentiate into several forms to ensure growth, replication, and eventual egress from the hepatocyte. These key transitions occur in specific subcellular locations during liver stage infection.

fraction of which have been described (Kaushansky et al., 2013a,b; Ruivo et al., 2016). Interrogating single proteins in a pathway to determine functionality is limiting in this context, and ignores secondary effects within the complex cell system. Instead, it is critical to comprehensively and quantitatively evaluate changes that occur during infection to illuminate mechanisms of control employed by the parasite.

\section{WHAT CAN SYSTEMS BIOLOGY DO FOR MALARIA?}

Understanding biology is a systems-level problem. Interactions between components of a system lead to the emergence of properties that cannot be understood from the study of the components individually. The study of systems biology is predicated on two basic assumptions. First, that the whole 
is far greater than the sum of its parts; and second, that a more comprehensive understanding of the components and their relationships within a system will allow for more accurate predictions of the system's behavior. It is through this lens that systems biology aims to determine the relationships and interactions of the components of a system. In practice, systems biology is a set of principles and processes by which we take complex systems apart and put them back together, with the aim of understanding the properties of the entire biological system. The approach generally starts with the systematic and comprehensive identification and quantification of molecules, called omics datasets, as a biological system transitions from one state to another. Initially, these data are evaluated using standard statistical tools, resulting in ordered lists, with significance values for each observed difference. These data provide the basis for the deployment of simple tools such as pathway analysis and clustering to interpret the data, or more complex analysis, such as regression or inference methods, to suggest causal or correlative relationships between components. These approaches can, and have, identified major molecular players at each stage, but fall short of a detailed and comprehensive understanding. Visualizing the data is also important for generating insights and predictive models that describe key determinants of the stage transition being interrogated (Figure 2). Predictions that are generated are then tested, often using "classic" or "reductionist" approaches. This process results in the refinement of both the model, and of our biological understanding. Molecular details are important, and systems biology must not ignore them. Examining the individual components of a system allows us to understand their molecular and physicochemical properties, as well as the function of the components in context of the entire system (Van Regenmortel, 2004). As the data that informs a model becomes more detailed, the predictions generated become more mechanistic. This level of insight is critical for rational intervention.

Modeling is not unique to systems biology. Indeed, all scientists generate "models," sometimes in the form of cartoons to aid in the design of the next line of inquiry. Systems biology models are often in the form of networks composed of balls and sticks, where balls (also called nodes) represent genes or proteins, and the sticks (or lines, also called edges) between them represent a relationship between molecular players. These simple visualizations can themselves facilitate the development of novel hypotheses. Many representations allow scientists to superimpose multiple types of data onto these networks (for example, molecule types, confidence of the interactions or subcellular organization). There are many popular and facile tools for these network visualizations (reviewed in Gehlenborg et al., 2010; Pavlopoulos et al., 2017). Once established, these networks can be mined to design subsequent experiments, and also used as a foundation for more complex models of the dynamics of molecular interactions and information flow. Depending on the complexity and the question to be addressed, models can take many forms. Some widely used approaches include Boolean networks, ordinary differential equations, and stochastic simulations. Different model classes involve different approximations, assumptions and levels of granularity. All models are best informed by quantitative, high quality, and biochemical data. While omics approaches can contribute to a more comprehensive view than possible with classical biochemical approaches, many models also incorporate data from rigorous reductionist approaches. Regardless of model class, the power of modeling lies in its capacity to capture insights that are difficult to reach through intuition alone.

Many of the technological and computational tools of systems biology are modular, and the resulting data can be integrated in different ways to inform the biological question (Danziger et al., 2014). Indeed, modeling biological data increasingly aims to incorporate a range of types of information, which monitor changes at different scales. This allows the researcher to determine what types of data are most informative when predicting a biological outcome of interest (Hwang et al., 2005a,b; Janes et al., 2005; Bonneau et al., 2007; AlQuraishi et al., 2014) and design subsequent experiments accordingly. Nevertheless, in most applications, applying computational analysis to quantitative datasets enables predictions (or new hypotheses) about how a perturbation, such as a gene deletion, drug treatment, or new environment, will influence the system as a whole.

\section{The Role of Quantitative and Comprehensive Datasets in Malaria Research}

In the case of malaria, numerous studies have generated omics data during life cycle transitions (Table 1). These include the cataloging of genes (genomics), mRNA transcripts (transcriptomics), translated protein (proteomics), metabolites (metabolomics), and translational repression/de-repression of transcripts as the parasite transitions through its life cycle stages. The genome of the Plasmodium parasite was initially published in 2002 (Gardner et al., 2002), and has been refined since. Initial transcriptomes and proteomes of $P$. yoelii and $P$. berghei Liver Stages have been generated, which have provided lists of the components involved in liver stage development, and further revealed the requirement of fatty acid synthesis from both the parasite and host during liver infection (Tarun et al., 2008; Albuquerque et al., 2009; Vaughan et al., 2009).

Insights that originate from transcriptomic analysis of Liver Stage infection reveal that Type I interferons and ER stress are systematically upregulated during liver stage infection and can modulate the level of liver stage infection (Liehl et al., 2014; Miller et al., 2014; Inacio et al., 2015; Kaushansky and Kappe, 2015a). Additional information can be obtained by monitoring changes in the parasite and host during infection under different environmental conditions. These, and related datasets can inform models that predict causality and cellular outcomes. The goal of this effort would be to identify networks of parasite and/or host factors that facilitate the development or demise of the parasite during its infection of the liver. 


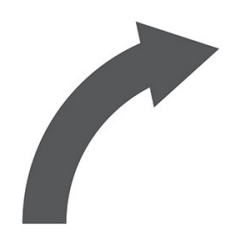

Model Refinement

(e.g. biological validation, targeted reductionist experimentation)

\section{Biological Question}

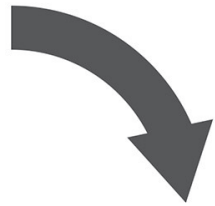

Quantitative Datasets

(e.g. omics data, other large datasets)

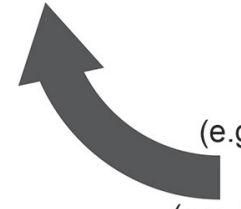

Quantitative Analysis

(e.g. clustering, differential regulation)

Data Visualization

(e.g. heat maps, network representations)

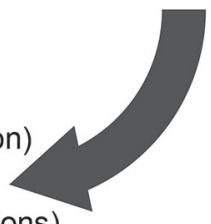

Modeling

(e.g. Boolean networks, differential

equations, machine learning)

FIGURE 2 | The processes involved in generating systems biology-informed models. To inform the biological question, quantitative datasets are generated, which are then used in quantitative analysis, data visualization, and modeling to describe how the system behaves. These tools can be used interchangeably and/or in succession before further refining the model. Refinement of the model can then provide new biological insights.

\section{Protein-Protein Interactions}

A major goal of host-pathogen studies is to elucidate specific interactions that dictate success or failure of the pathogen. While transcriptomics and proteomics can catalog changes that occur in the infected cell, a list of alterations alone does not provide mechanistic insight, and is unsatisfying to most cell biologists. Databases of protein interactions in many organisms, including humans, are becoming highly populated (Hein et al., 2015; Huttlin et al., 2015). Yet, many immunopurificationmass-spectrometry (IP-MS) based approaches to study proteinprotein interactions do not meet the standard of quantitative and comprehensive. As datasets become larger, statistical tools can be used to predict which interactions are more likely to be specific, compared to commonly identified (abundant or promiscuous) proteins (Mellacheruvu et al., 2013). The pitfalls of qualitative and low throughput data have been partially overcome in model organisms such as yeast, where whole-genome GFP tag libraries have been generated and used in IP-MS experiments, although even these datasets remain incomplete, and are error prone (Ghaemmaghami et al., 2003; Huh et al., 2003; Mellacheruvu et al., 2013).

More sophisticated approaches designed to distinguish between bona fide and spurious interactions are being developed and applied. For example, Isotopic Differentiation of Interactions as Random or Targeted (I-DIRT) and variants (Tackett et al., 2005; Selbach and Mann, 2006; Trinkle-Mulcahy et al., 2008; Byrum et al., 2012; Trinkle-Mulcahy, 2012) exploit isotopic labeling and immunopurification to distinguish between interactions that occur before cell lysis, from those interactions that are introduced during the purification process. While these approaches improve confidence in interactions, they are neither widely adopted, nor have they been applied in genome scale studies.

\section{The Role of Imaging in Defining Quantitative Stage Transitions}

Since the initial discovery of liver stage parasites by microscopy in 1948 (Shortt and Garnham, 1948), imaging has been an invaluable tool of malaria research. However, most common imaging methods are neither quantitative nor comprehensive, limiting their capacity to inform modeling approaches. This is particularly troubling for applying a systems biology approach, as cellular outcomes are what we aim to predict, but are often poorly defined. Traditional imaging also falls short of reaching the temporal resolution necessary to elucidate the dynamic cellular processes during invasion and throughout liver stage infection.

A number of new imaging modalities enhance our ability to increase resolution, quantification and throughput. A comprehensive review of the advances made in increasing throughput, quantification and resolution in the imaging field is outside the scope of this review, we will highlight some examples that are particularly relevant to malaria research. One example, correlated light microscopy and electron microscopy (CLEM) combines fluorescence microscopy with electron microscopy, thereby increasing the throughput of monitoring rare events like liver stage infection at EM-level resolution (van Rijnsoever et al., 2008), and has already been applied to monitor liver stage development (Grutzke et al., 2014). Intravital imaging (IVM) has been adapted for malaria research and facilitates analysis of live tissue with microscopic resolution to reveal cellular responses that closely mimic in vivo infection, both spatially and temporally 
(Pittet and Weissleder, 2011; De Niz et al., 2017). Additional instrumentation, such as the Lattice Light Sheet Microscope (Betzig et al., 2006), enhances temporal and spatial resolution, with applications in both in vivo and in vitro systems, which could enable a more quantitative assessment of cellular outcomes.

\section{The Power of New Genetic Tools and Screens in Determining Function}

An essential component of systems biology is the experimental testing of predictions made by modeling efforts. This testing is greatly assisted by the capacity to perform genetic perturbations. Indeed, one of the major shortfalls of employing systems biology is that testing predictions is largely performed by single candidate-based approaches, and thus often fails to recapitulate the complexity of the system. In many cases, it remains difficult to determine if the model is incorrect, or if reductionist approaches cannot fully capture the emergent properties associated with a complex system. New genome-editing approaches, like CRISPR/Cas, can assess multiple perturbations in combination, in both mammalian and parasite genomes, which will facilitate testing more complex models (Cong et al., 2013; Mali et al., 2013; Ghorbal et al., 2014; Wagner et al., 2014; Lu et al., 2016).

In addition to evaluating individual or groups of gene candidates for function, new genome-editing approaches also have the ability to globally evaluate both host and parasite genes. Whole genome CRISPR/Cas9 knockout screens are now common in mammalian cells (Cong et al., 2013; Mali et al., 2013) and can be adapted to the Plasmodium genome. The Plasmodium Genetic Modification Project (PlasmoGEM), a new community resource from the Wellcome Trust Sanger Institute, aims to produce new tools for the genetic modification of malaria parasites at genome scale. This resource has already demonstrated that two-thirds of $P$. berghei genes contribute to normal blood stage development (Bushell et al., 2017). Subsequent studies should not only focus on the role of parasite genes in other life cycle stages, but also interrogate the role of host genes during each stage of parasite development.

\section{KEY QUESTIONS AND FINDINGS IN MALARIA LIVER STAGE BIOLOGY}

The existing literature provides a basis upon which global experiments can be designed and modeled, and also highlights the most critical questions that remain. Given the potential and increasing power of systems biology, the challenge lies in how to use this approach to bolster the rich collection of findings that have been amassed by the Plasmodium research community, and address hurdles that have been unattainable by more traditional approaches. In this next section, we focus on some of the key findings on liver stage malaria with an emphasis on questions that remain.

\section{Hepatocyte Invasion}

During hepatocyte invasion, the parasite attaches to the host cell, at least partially through circumsporozoite protein (CSP), which interacts directly with highly sulfated proteoglycans (HSPGs) on the cell surface to trigger CSP cleavage, inducing the sporozoite to switch to an invasive state (Table 2A) (Coppi et al., 2007, 2011). Thrombospondin-related anonymous protein (TRAP) is also involved in this process (Kappe et al., 1999; Matuschewski et al., 2002; Morahan et al., 2009). Additionally, Plasmodium proteins P36 and P52 play a role in invasion, parasitophorous vacuole membrane (PVM) formation, and protecting the host against apoptosis (Ishino et al., 2005; van Dijk et al., 2005; Ploemen et al., 2012). How each of these factors works in concert to facilitate productive invasion of the hepatocyte remains unknown.

A collection of host factors have also been described to impact parasite infection (Table 2B). Scavenger Receptor B1 (SRB1) and the tetraspanin CD81 both play roles in cholesterol-rich microdomain formation and are critical for hepatocyte invasion (Silvie et al., 2003; Rodrigues et al., 2008; Yalaoui et al., 2008a; Valacchi et al., 2011). More recently, it has been described that CD81 and SRB1 are involved in invasion in different species; CD81 is required for $P$. yoelii and $P$. falciparum infection, but appears to be dispensable for $P$. berghei and $P$. vivax infection. SRB1 plays a more substantial role in $P$. vivax and $P$. berghei infections (Silvie et al., 2003; Manzoni et al., 2017). It remains unknown if either protein makes contact with the sporozoite, although it has been suggested that SRB1 might directly engage the parasite, whereas CD81 indirectly impacts infection (Yalaoui et al., 2008b; Manzoni et al., 2017). The receptor tyrosine kinase EphA2 is also critical for hepatocyte infection, at least in part by engaging the parasite protein P36 (Kaushansky et al., 2015). While each of these factors contributes to the infection process, how they work in concert, and how changes in one invasion factor impacts another remain unknown. New approaches that integrate biochemical information and omics datasets are well-suited to merge with existing candidate-based research to create a more comprehensive view of the molecular components required for hepatocyte invasion (AlQuraishi et al., 2014; Gujral et al., 2014). The capacity to integrate biochemical data into a more global framework also paves the way for the identification of molecules or networks that could be targeted for intervention.

\section{Liver Stage Development}

Once the parasite has taken up residence in the hepatocyte, the sporozoite dedifferentiates over the course of $12 \mathrm{~h}$ in rodents, or 2-3 days in humans. This process results in a rounded trophozoite, which is characterized by dramatic changes in the parasite including the disassembly of molecular and cellular structures and the expulsion of invasion machinery (Bano et al., 2007) (reviewed in Kaushansky and Kappe, 2015b; Vaughan and Kappe, 2017). Following dedifferentiation, schizogony begins, which involves the massive replication the genome, and takes place over the course of 2-10 days, depending on the Plasmodium species. During this time, cellular structures including lysosomes and late endosomes sequester around the parasitophorous vacuole membrane and associate with the tubovesicular network (Lopes da Silva et al., 2012; Grutzke et al., 2014). The unfolded protein response is triggered, which promotes endoplasmic reticulum stress and the survival of the Liver Stage parasite (Inacio et al., 2015; Kaushansky and Kappe, 2015a). The most 
TABLE 2 | Determinants of hepatocyte liver stage infection: (A) Plasmodium determinants of infection and (B) Host determinants of infection.

\begin{tabular}{|c|c|c|c|}
\hline Host/Parasite factor & Stage of infection & Main findings & References \\
\hline \multicolumn{4}{|l|}{ (A) } \\
\hline SPECT & Traversal & Essential for cell traversal & Ishino et al., 2004, 2005 \\
\hline PLP1 (SPECT2) & & Essential for cell traversal & Ishino et al., 2004, 2005 \\
\hline CelTOS & & Hypothesized to play a role in the exit step of traversal & Kariu et al., 2006 \\
\hline TRAP-like protein (TLP) & & TLP-deficient sporozoites show a diminished ability to traverse & Moreira et al., 2008 \\
\hline PL (UIS10) & Hepatocyte Invasion & PL-deficient sporozoites show reduction in Liver Stage burden & Bhanot et al., 2005 \\
\hline $\begin{array}{l}\text { Circumsporozoite protein } \\
\text { (CSP) }\end{array}$ & & $\begin{array}{l}\text { Multiple roles in motility and invasion, including transition from } \\
\text { traversing state to invasive state }\end{array}$ & Coppi et al., 2007 \\
\hline P36 & & Contributes to PVM formation & $\begin{array}{l}\text { Ishino et al., 2005; Labaied et al., } \\
2007\end{array}$ \\
\hline P52/P36p & & Contributes to PVM formation & $\begin{array}{l}\text { Ishino et al., 2005; Labaied et al., } \\
2007\end{array}$ \\
\hline Cysteine proteases & & $\begin{array}{l}\text { Inhibition of sporozoite cysteine proteases completely inhibits } \\
\text { infectivity }\end{array}$ & Coppi et al., 2005 \\
\hline $\begin{array}{l}\text { Calcium Dependent Protein } \\
\text { Kinase-6 (CDPK-6) }\end{array}$ & & $\begin{array}{l}\text { Sporozoites from CDPK-6-deficient parasites show decrease in } \\
\text { invasion and CSP cleavage }\end{array}$ & Coppi et al., 2007 \\
\hline TRAP & & Direct role in invasion through attachment with cytoplasmic tail & $\begin{array}{l}\text { Kappe et al., 1999; } \\
\text { Matuschewski et al., 2002; } \\
\text { Morahan et al., } 2009\end{array}$ \\
\hline $\begin{array}{l}\text { Upregulated in Sporozoite } 4 \\
\text { (UIS4) }\end{array}$ & Liver stage Development & $\begin{array}{l}\text { UIS4-deficient } P \text {. berghei parasites severely impaired in Liver Stage } \\
\text { development }\end{array}$ & Mueller et al., 2005 \\
\hline $\begin{array}{l}\text { Upregulated in Sporozoite } \\
\text { (UIS3) }\end{array}$ & & $\begin{array}{l}\text { UIS3-deficient parasites severely impaired in Liver Stage } \\
\text { development. UIS3 has been hypothesized to play a role in fatty } \\
\text { acid uptake }\end{array}$ & Mikolajczak et al., 2007 \\
\hline EXP1 & & $\begin{array}{l}\text { Interacts with host Apolipoprotein } \mathrm{H} \text { to promote liver stage } \\
\text { development }\end{array}$ & Sa et al., 2017 \\
\hline LISP2 & & $\begin{array}{l}\text { Hypothesized to be involved in merozoite formation and exported } \\
\text { to host cytosol }\end{array}$ & Orito et al., 2013 \\
\hline B9 & & P9 mutants show liver stage growth arrest & Annoura et al., 2014 \\
\hline Sequestrin & & $\begin{array}{l}\text { Mutants lacking sequestrin show a reduction in liver stage } \\
\text { development }\end{array}$ & Annoura et al., 2014 \\
\hline MSP1 & & $\begin{array}{l}\text { Conditional mutagenesis of MSP1 in sporozoites impaired } \\
\text { merozoite formation }\end{array}$ & Combe et al., 2009 \\
\hline LISP1 & Hepatocyte Exit & In P. berghei, LISP1 is required for lysis of the PVM prior to egress & Ishino et al., 2009 \\
\hline SUB1 & & $\begin{array}{l}\text { SUB1-deficient } P \text {. berghei parasites fail to rupture the PVM prior to } \\
\text { egress }\end{array}$ & Tawk et al., 2013 \\
\hline \multicolumn{4}{|l|}{ (B) } \\
\hline CD68 & Traversal & Putative receptor of Kupffer cells, gateway for liver stage infection & Cha et al., 2016 \\
\hline Hepatocyte Growth Factor & Hepatocyte Invasion & $\begin{array}{l}\text { Secretion of HGF renders } P \text {. berghei host hepatocytes susceptible } \\
\text { to infection }\end{array}$ & Carrolo et al., 2003 \\
\hline CD81 & & Required on hepatocytes for $P$. yoelii invasion with PVM formation & Silvie et al., 2003 \\
\hline Cholesterol & & Involved in assembly of CD81 microdomains on the cell surface & Silvie et al., 2003, 2006, 2007 \\
\hline HSPGs & & $\begin{array}{l}\text { Binds CSP, increased sulfation on HSPGs triggers invasion of } \\
\text { migrating sporozoite }\end{array}$ & $\begin{array}{l}\text { Frevert et al., 1993; Coppi et al., } \\
2007\end{array}$ \\
\hline EphA2 & & Engages parasite protein P36 to facilitate hepatocyte invasion & Kaushansky et al., 2015 \\
\hline Scavenger Receptor B1 & & $\begin{array}{l}\text { Required for CD81 microdomain formation, additional roles } \\
\text { independent of CD81 for } P \text {. berghei and } P \text {. vivax }\end{array}$ & $\begin{array}{l}\text { Rodrigues et al., 2008; Yalaoui } \\
\text { et al., 2008a; Manzoni et al., } \\
2017\end{array}$ \\
\hline HGF/MET signaling & Liver Stage Development & $\begin{array}{l}\text { Prevents the apoptosis of } P \text {. berghei infected cells, promoting } \\
\text { successful infection }\end{array}$ & Leiriao et al., 2005 \\
\hline Endosomes and lysosomes & & $\begin{array}{l}\text { Endosomes and lysosomes are localized around the PVM during } \\
\text { development }\end{array}$ & $\begin{array}{l}\text { Lopes da Silva et al., 2012; } \\
\text { Grutzke et al., } 2014\end{array}$ \\
\hline
\end{tabular}


TABLE 2 | Continued

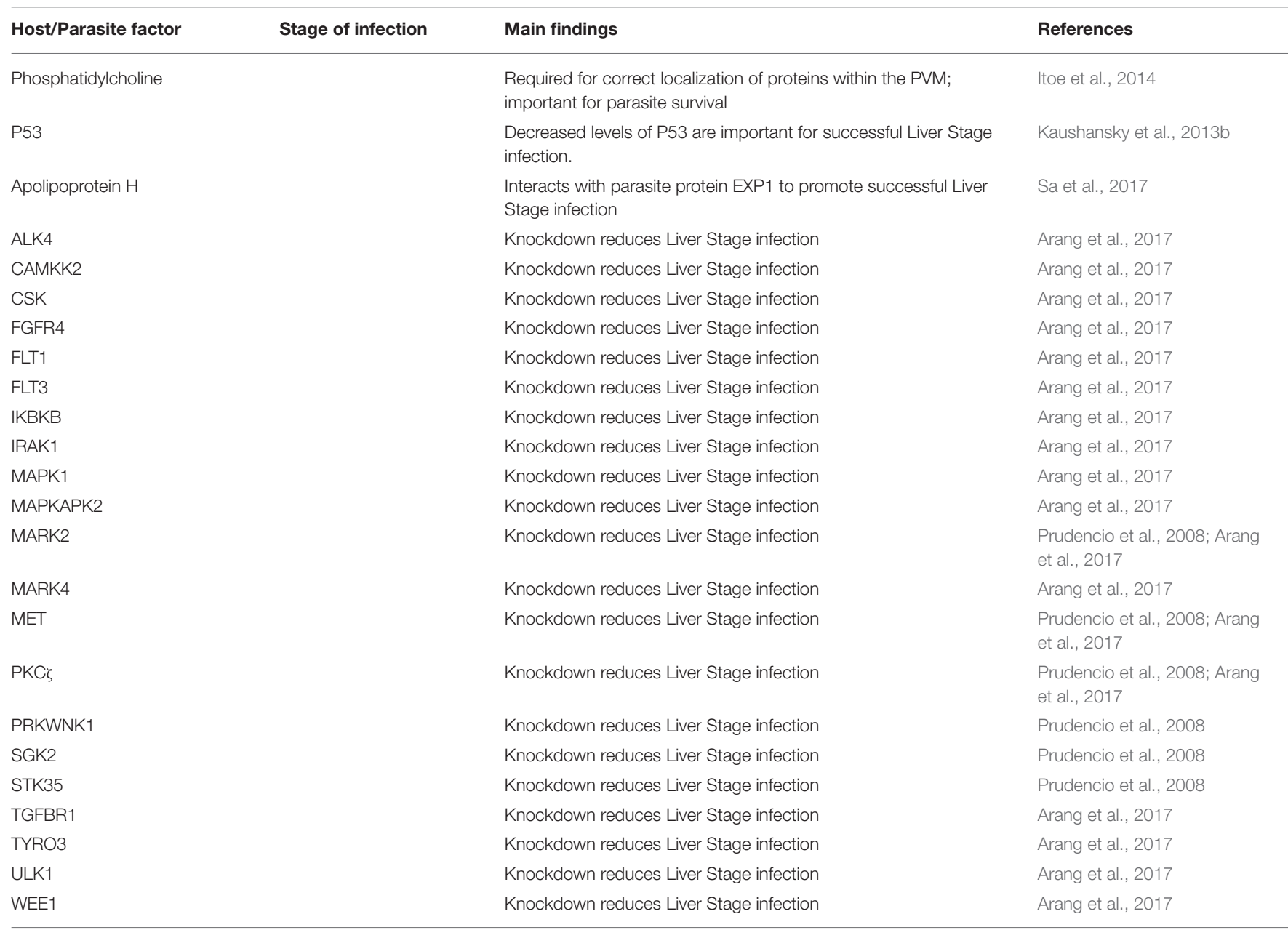

dramatic change, however, is the replication of the liver stage schizont, which produces tens of thousands of merozoites (membrane-bound, haploid, red blood cell invasive forms) that eventually invade erythrocytes during blood stage development. During this process, some parasites survive, and re-wire their host cells to resist certain types of apoptotic stimuli, while others succumb to host cell apoptosis or alternative cell death stimuli (Leiriao et al., 2005; van de Sand et al., 2005; Kaushansky et al., 2013a,b; Douglass et al., 2015). While these dramatic cellular changes have been qualitatively observed, they are rarely monitored quantitatively.

Some molecular determinants have been linked to Liver Stage survival and development. For example, Plasmodium proteins Upregulated in Infectious Sporozoites (UIS) UIS3 and UIS4 have been hypothesized to play an active role in host nutrient acquisition, in part because of the demonstration that UIS3 associates with the host Liver Fatty Acid Binding Protein (LFABP) (Mikolajczak et al., 2007; Blume et al., 2011; Slavic et al., 2011; Favretto et al., 2013) and localizes both proteins to the PVM (Mueller et al., 2005). Fatty acids of both host and parasite origin, including host phosphatidylcholine, have been demonstrated to be required for optimal liver stage development (Mazumdar et al., 2006; Vaughan et al., 2009; Itoe et al., 2014). How each of these components specifically contributes to the observed cellular changes, and how each factor co-opts host defenses remains unknown. A more quantitative assessment of the cellular changes that occur, matched to molecular information, will enable the development of models that describe networks of host-parasite interactions required for development of the liver stage parasite.

\section{Liver Stage Exit}

Intracellular pathogens must exit their host cell in order to propagate and survive. The precise strategies they use directly impact their ability to disseminate within a host, transmit to new hosts, and engage or avoid host immune responses. Despite these important functions of exit, detailed investigations into the mechanisms governing Plasmodium exit have been lacking. This process is important not only for our basic understanding of liver stage development, but also for immunity. This is illustrated by the finding that the most potent stimulus of the immune system is elicited by parasites that develop through the liver stage and exit, but cannot undergo replication within the blood stage (Bijker et al., 2013). 
Egress from hepatocytes occurs through the rupture of the PVM, followed by destabilization of the actin cytoskeleton, to allow the budding of merozoites from the host cell through the formation of merozoite-filled vesicles (merosomes). These structures are surrounded by a membrane of host origin (Graewe et al., 2011), and have been hypothesized to shuttle merozoites into the bloodstream to begin blood stage infection (Burda et al., 2017). This process inhibits exposure of phosphatidylserine (PS) on the outer surface of the cell, thereby simultaneously ensuring migration of parasites to the bloodstream and protection from host immune responses (Sturm et al., 2006; Tarun et al., 2006; Baer et al., 2007). Recent methodological advances have developed a platform for quantifying exit events (Stanway et al., 2009). This quantification, and a global assessment of molecular changes that occur during exit, will drive the development of models that describe networks of host-parasite interactions that underlie the exit process. Importantly, these networks could then be used to predict host and parasite determinants of dissemination to the blood stream, and the ability to engage or avoid host immune responses.

\section{CONCLUSIONS AND NEW DIRECTIONS}

Parasites must successfully navigate a wide variety of different environmental milieus, and each alternative setting presents challenges for the parasite, as well as opportunities for intervention. Here, we have described how the tools and approaches of systems biology can be deployed to more comprehensively characterize the complex interaction between parasite and host. This will inform our understanding of how the parasite and the host interact, and also facilitate future strategies to combat the parasite. Interventions that have been designed and employed without a comprehensive understanding of the complex dynamic between the Plasmodium parasite and its host have only partially controlled malaria in the field.

Despite the challenges, many influential leaders have called for malaria eradication in recent years (Gates, 2007; WHO, 2017). This goal is most likely to be realized if control strategies are

\section{REFERENCES}

Albuquerque, S. S. Carret, C., Grosso, A. R., Tarun, A. S., Peng, X., Kappe, S. H., et al. (2009). Host cell transcriptional profiling during malaria liver stage infection reveals a coordinated and sequential set of biological events. BMC Genomics 10:270. doi: 10.1186/1471-2164-10-270

AlQuraishi, M., Koytiger, G., Jenney, A., MacBeath, G., and Sorger, P. K. (2014). A multiscale statistical mechanical framework integrates biophysical and genomic data to assemble cancer networks. Nat. Genet. 46, 1363-1371. doi: $10.1038 /$ ng. 3138

Annoura, T., van Schaijk, B. C., Ploemen, I. H., Sajid, M., Lin, J. W., Vos, M. W., et al. (2014). Two Plasmodium 6-Cys family-related proteins have distinct and critical roles in liver-stage development. FASEB J. 28, 2158-2170. doi: 10.1096/fj.13-241570

Arang, N., Kain, H. S., Glennon, E. K., Bello, T., Dudgen, D. R., Walter, E. N. F., et al. (2017). Identifying host regulators and inhibitors of liver stage malaria infection using kinase activity profiles. Nat. Commun. 8:1232. doi: 10.1038/s41467-017-01 345-2 deployed rationally with the capacity to predict how a given treatment will impact systematic changes in the parasite and host alike, to facilitate readiness for these changes. The integration of systems biology could evaluate the capacity of the parasite to circumvent new interventions, and in doing so, contribute to the success of eradication efforts. While references to the principles of systems biology first occurred decades ago, the field was established in earnest $\sim 15$ years ago with the completion of the human genome. Since then, most systems biology studies have steered clear of the complexity that is introduced when multiple genomes collide, as is the case during infection. Pathogens and their host cells have coevolved, introducing alterations to both genomes along the way (Miller et al., 1976; Zimmerman et al., 2013). What has resulted is the capacity of a pathogen to fundamentally alter the biology of its host, by changing the size, shape, composition and function of the cell. Intracellular pathogens thus are expert cell biologists, controlling the host cell to their own advantage. As such, the study of hostpathogen interactions presents an unmatched opportunity for the field of systems biology, just as the approach of systems biology presents an unmatched opportunity for the eradication of malaria.

\section{AUTHOR CONTRIBUTIONS}

MZ, LSA, SAD, JDA, and AK were involved in the conception of the article. MZ, JDA, and AK wrote the article with assistance from LSA and SAD.

\section{ACKNOWLEDGMENTS}

We would like to acknowledge Zach Grossnickle and Marissa Vignali for assistance with figure design. We thank Jarrod Johnson and Thurston Herricks for critical review of the manuscript. Funding for this review was provided by NIH 1R01GM101183, R21AI124266, 1K99/R00AI111785, P50 GM076547, P41 GM109824, R01 GM112108, and Center for Infectious Disease Research Internal Funding.

Baer, K., Klotz, C., Kappe, S. H., Schnieder, T., and Frevert, U. (2007). Release of hepatic Plasmodium yoelii merozoites into the pulmonary microvasculature. PLoS Pathog. 3:e171. doi: 10.1371/journal.ppat.0030171

Bano, N., Romano, J. D., Jayabalasingham, B., and Coppens, I. (2007). Cellular interactions of Plasmodium liver stage with its host mammalian cell. Int. J. Parasitol. 37, 1329-1341. doi: 10.1016/j.ijpara.2007.04.005

Betzig, E., Patterson, G. H., Sougrat, R., Lindwasser, O. W., Olenych, S., Bonifacino, J. S., et al. (2006). Imaging intracellular fluorescent proteins at nanometer resolution. Science 313, 1642-1645. doi: 10.1126/science.11 27344

Bhanot, P., Schauer, K., Coppens, I., and Nussenzweig, V. (2005). A surface phospholipase is involved in the migration of plasmodium sporozoites through cells. J Biol Chem. 280, 6752-6760. doi: 10.1074/jbc.M4114 65200

Bijker, E. M., Bastiaens, G. J., Teirlinck, A. C., van Gemert, G. J., Graumans, W., M. van de Vegte-Bolmer, et al. (2013). Protection against malaria after immunization by chloroquine prophylaxis and sporozoites is mediated by preerythrocytic immunity. Proc. Natl. Acad. Sci. U.S.A. 110, 7862-7867. doi: $10.1073 /$ pnas. 1220360110 
Blasco, B., Leroy, D., and Fidock, D. A. (2017). Antimalarial drug resistance: linking Plasmodium falciparum parasite biology to the clinic. Nat. Med. 23, 917-928. doi: 10.1038/nm.4381

Blume, M., Hliscs, M., Rodriguez-Contreras, D., Sanchez, M., Landfear, S., Lucius, R., et al. (2011). A constitutive pan-hexose permease for the Plasmodium life cycle and transgenic models for screening of antimalarial sugar analogs. FASEB J. 25, 1218-1229. doi: 10.1096/fj.10-173278

Bonneau, R., Facciotti, M. T., Reiss, D. J., Schmid, A. K., Pan, M., Kaur, A., et al. (2007). A predictive model for transcriptional control of physiology in a free living cell. Cell 131, 1354-1365. doi: 10.1016/j.cell.2007. 10.053

Burda, P. C., Caldelari, R., and Heussler, V. T. (2017). Manipulation of the host cell membrane during plasmodium liver stage egress. MBio. 8:17. doi: $10.1128 / \mathrm{mBio} .00139-17$

Bushell, E., Gomes, A. R., Sanderson, T., Anar, B., Girling, G., Herd, C., et al. (2017). Functional profiling of a plasmodium genome reveals an abundance of essential genes. Cell 170, 260-272 e8. doi: 10.1016/j.cell.2017.06.030

Byrum, S., Smart, S. K., Larson, S., and Tackett, A. J. (2012). Analysis of stable and transient protein-protein interactions. Methods Mol. Biol. 833, 143-152. doi: 10.1007/978-1-61779-477-3_10

Carrolo, M., Giordano, S., Cabrita-Santos, L., Corso, S., Vigario, A. M., Silva, S., et al. (2003). Hepatocyte growth factor and its receptor are required for malaria infection. Nat. Med. 9, 1363-1369. doi: 10.1038/nm947

Cha, S. J., Kim, M. S., Pandey, A., and Jacobs-Lorena, M. (2016). Identification of GAPDH on the surface of Plasmodium sporozoites as a new candidate for targeting malaria liver invasion. J. Exp. Med. 213, 2099-2112. doi: 10.1084/jem.20160059

Coleman, B. I., Skillman, K. M., Jiang, R. H. Y., Childs, L. M., Altenhofen, L. M., Ganter, M., et al. (2014). A Plasmodium falciparum histone deacetylase regulates antigenic variation and gametocyte conversion. Cell Host Microbe 16, 177-186. doi: 10.1016/j.chom.2014.06.014

Combe, A., Giovannini, D., Carvalho, T. G., Spath, S., Boisson, B., Loussert, C., et al. (2009). Clonal conditional mutagenesis in malaria parasites. Cell Host Microbe 5, 386-396. doi: 10.1016/j.chom.2009.03.008

Cong, L., Ran, F. A., Cox, D., Lin, S., Barretto, R., Habib, N., et al. (2013). Multiplex genome engineering using CRISPR/Cas systems. Science 339, 819-823. doi: 10.1126/science. 1231143

Coppi, A., Natarajan, R., Pradel, G., Bennett, B. L., James, E. R., Roggero, M. A., et al. (2011). The malaria circumsporozoite protein has two functional domains, each with distinct roles as sporozoites journey from mosquito to mammalian host. J. Exp. Med. 208, 341-356. doi: 10.1084/jem.201 01488

Coppi, A., Pinzon-Ortiz, C., Hutter, C., and Sinnis, P. (2005). The Plasmodium circumsporozoite protein is proteolytically processed during cell invasion. J. Exp. Med. 201, 27-33. doi: 10.1084/jem.20040989

Coppi, A., Tewari, R., Bishop, J. R., Bennett, B. L., Lawrence, R., Esko, J. D., et al. (2007). Heparan sulfate proteoglycans provide a signal to Plasmodium sporozoites to stop migrating and productively invade host cells. Cell Host Microbe 2, 316-327. doi: 10.1016/j.chom.2007.10.002

Danziger, S. A. Ratushny, A. V., Smith, J. J., Saleem, R. A., Wan, Y., Arens, C. E., et al. (2014). Molecular mechanisms of system responses to novel stimuli are predictable from public data. Nucleic Acids Res. 42, 1442-1460. doi: 10.1093/nar/gkt938

De Niz, M., Burda, P. C., Kaiser, G., Del Portillo, H. A., Spielmann, T., Frischknecht, F., et al. (2017). Progress in imaging methods: insights gained into Plasmodium biology. Nat. Rev. Microbiol. 15, 37-54. doi: $10.1038 /$ nrmicro.2016.158

Douglass, A. N., Kain, H. S., Abdullahi, M., Arang, N., Austin, L. S., Mikolajczak, S. A., et al. (2015). Host-based prophylaxis successfully targets liver stage malaria parasites. Mol. Ther. 23, 857-865. doi: 10.1038/mt.2015.18

Favretto, F., Assfalg, M., Molinari, H., and D’Onofrio, M. (2013). Evidence from NMR interaction studies challenges the hypothesis of direct lipid transfer from L-FABP to malaria sporozoite protein UIS3. Protein Sci. 22, 133-138. doi: 10.1002 /pro. 2194

Frevert, U., Sinnis, P., Cerami, C., Shreffler, W., Takacs, B., and Nussenzweig, V. (1993). Malaria circumsporozoite protein binds to heparan sulfate proteoglycans associated with the surface membrane of hepatocytes. J. Exp. Med. 177, 1287-1298. doi: 10.1084/jem.177.5.1287
Gardner, M. J., Hall, N., Fung, E., White, O., Berriman, M., and Hyman, R. W. (2002). Genome sequence of the human malaria parasite Plasmodium falciparum. Nature 419, 498-511. doi: 10.1038/nature01097

Gates, M. (2007). Malaria Forum Keynote Address. Available online at: https:// www.gatesfoundation.org/media-center/speeches/2007/10/melinda-frenchgates-malaria-forum

Gehlenborg, N., O’Donoghue, S. I., Baliga, N. S., Goesmann, A., Hibbs, M. A., Kitano, H., et al. (2010). Visualization of omics data for systems biology. Nat. Methods 7, S56-S68. doi: 10.1038/nmeth.1436

Ghaemmaghami, S., Huh, W. K., Bower, K., Howson, R. W., Belle, A., Dephoure, N., et al. (2003). Global analysis of protein expression in yeast. Nature 425, 737-741. doi: 10.1038/nature02046

Ghorbal, M., Gorman, M., Macpherson, C. R., Martins, R. M., Scherf, A., and Lopez-Rubio, J. J. (2014). Genome editing in the human malaria parasite Plasmodium falciparum using the CRISPR-Cas9 system. Nat. Biotechnol. 32, 819-821. doi: 10.1038/nbt.2925

Gomes-Santos, C. S., Braks, J., Prudencio, M., Carret, C., Gomes, A. R., Pain, A., et al. (2011). Transition of Plasmodium sporozoites into liver stage-like forms is regulated by the RNA binding protein Pumilio. PLoS Pathog. 7:e1002046. doi: 10.1371/journal.ppat.1002046

Graewe, S., Rankin, K. E., Lehmann, C., Deschermeier, C., Hecht, L., Froehlke, U., et al. (2011). Hostile takeover by Plasmodium: reorganization of parasite and host cell membranes during liver stage egress. PLoS Pathog. 7:e1002224. doi: 10.1371/journal.ppat.1002224

Grutzke, J., Rindte, K., Goosmann, C., Silvie, O., Rauch, C., Heuer, D., et al. (2014). The spatiotemporal dynamics and membranous features of the Plasmodium liver stage tubovesicular network. Traffic 15, 362-382. doi: 10.1111/tra.12151

Guerreiro, A., Deligianni, E., Santos, J. M., Silva, P. A., Louis, C., Pain, A., et al. (2014). Genome-wide RIP-Chip analysis of translational repressorbound mRNAs in the Plasmodium gametocyte. Genome Biol. 15:493. doi: 10.1186/s13059-014-0493-0

Gujral, T. S., Peshkin, L., and Kirschner, M. W. (2014). Exploiting polypharmacology for drug target deconvolution. Proc. Natl. Acad. Sci. U.S.A. 111, 5048-5053. doi: 10.1073/pnas.1403080111

Hein, M. Y., Hubner, N. C., Poser, I., Cox, J., Nagaraj, N., Toyoda, Y., et al. (2015). A human interactome in three quantitative dimensions organized by stoichiometries and abundances. Cell 163, 712-723. doi: 10.1016/j.cell.2015.09.053

Huh, W. K., Falvo, J. V., Gerke, L. C., Carroll, A. S., Howson, R. W., Weissman, J. S., et al. (2003). Global analysis of protein localization in budding yeast. Nature 425, 686-691. doi: 10.1038/nature02026

Huttlin, E. L., Ting, L., Bruckner, R. J., Gebreab, F., Gygi, M. P., Szpyt, J., et al. (2015). The BioPlex network: a systematic exploration of the human interactome. Cell 162, 425-440. doi: 10.1016/j.cell.2015.06.043

Hwang, D., Rust, A. G., Ramsey, S., Smith, J. J., Leslie, D. M., Weston, A. D., et al. (2005a). A data integration methodology for systems biology. Proc. Natl. Acad. Sci. U.S.A. 102, 17296-17301. doi: 10.1073/pnas.0508647102

Hwang, D., Smith, J. J., Leslie, D. M., Weston, A. D., Rust, A. G., Ramsey, S., et al. (2005b). A data integration methodology for systems biology: experimental verification. Proc. Natl. Acad. Sci. U.S.A. 102, 17302-17307. doi: 10.1073/pnas.0508649102

Inacio, P., Zuzarte-Luis, V., Ruivo, M. T., Falkard, B., Nagaraj, N., Rooijers, K., et al. (2015). Parasite-induced ER stress response in hepatocytes facilitates Plasmodium liver stage infection. EMBO Rep. 16, 955-964. doi: 10.15252/embr.201439979

Ishino, T., Boisson, B., Orito, Y., Lacroix, C., Bischoff, E., Loussert, C., et al. (2009). LISP1 is important for the egress of Plasmodium berghei parasites from liver cells. Cell. Microbiol. 11, 1329-1339. doi: 10.1111/j.1462-5822.2009.01333.x

Ishino, T., Chinzei, Y., and Yuda, M. (2005). Two proteins with 6-cys motifs are required for malarial parasites to commit to infection of the hepatocyte. Mol. Microbiol. 58, 1264-1275. doi: 10.1111/j.1365-2958.2005.04801.x

Ishino, T., Yano, K., Chinzei, Y., and Yuda, M. (2004). Cell-passage activity is required for the malarial parasite to cross the liver sinusoidal cell layer. PLoS Biol. 2:E4. doi: 10.1371/journal.pbio.0020004

Itoe, M. A., Sampaio, J. L., Cabal, G. G., Real, E., Zuzarte-Luis, V., March, S., et al. (2014). Host cell phosphatidylcholine is a key mediator of malaria parasite survival during liver stage infection. Cell Host Microbe 16, 778-786. doi: 10.1016/j.chom.2014.11.006 
Janes, K. A., Albeck, J. G., Gaudet, S., Sorger, P. K., Lauffenburger, D. A., and Yaffe, M. B. (2005). A systems model of signaling identifies a molecular basis set for cytokine-induced apoptosis. Science 310, 1646-1653. doi: 10.1126/science.1116598

Joice, R., Nilsson, S. K., Montgomery, J., Dankwa, S., Egan, E., Morahan, B., et al. (2014). Plasmodium falciparum transmission stages accumulate in the human bone marrow. Sci. Transl. Med. 6:244re5. doi: 10.1126/scitranslmed.3008882

Kafsack, B. F., Rovira-Graells, N., Clark, T. G., Bancells, C., Crowley, V. M., Campino, S. G., et al. (2014). A transcriptional switch underlies commitment to sexual development in malaria parasites. Nature 507, 248-252. doi: 10.1038 /nature12920

Kappe, S., Bruderer, T., Gantt, S., Fujioka, H., Nussenzweig, V., and Menard, R. (1999). Conservation of a gliding motility and cell invasion machinery in Apicomplexan parasites. J. Cell Biol. 147, 937-944. doi: 10.1083/jcb.147.5.937

Kariu, T., Ishino, T., Yano, K., Chinzei, Y., and Yuda, M. (2006). CelTOS, a novel malarial protein that mediates transmission to mosquito and vertebrate hosts. Mol. Microbiol. 59, 1369-1379. doi: 10.1111/j.1365-2958.2005.05024.x

Kaushansky, A., Douglass, A. N., Arang, N., Vigdorovich, V., Dambrauskas, N., Kain, H. S., et al. (2015). Malaria parasites target the hepatocyte receptor EphA2 for successful host infection. Science 350, 1089-1092. doi: $10.1126 /$ science.aad 3318

Kaushansky, A., and Kappe, S. H. (2015a). Host ER stress during malaria parasite infection. EMBO Rep. 16, 883-884. doi: 10.15252/embr.201540792

Kaushansky, A., and Kappe, S. H. (2015b). Selection and refinement: the malaria parasite's infection and exploitation of host hepatocytes. Curr. Opin. Microbiol. 26, 71-78. doi: 10.1016/j.mib.2015.05.013

Kaushansky, A., Metzger, P. G., Douglass, A. N., Mikolajczak, S. A., Lakshmanan, V., Kain, H. S., et al. (2013a). Malaria parasite liver stages render host hepatocytes susceptible to mitochondria-initiated apoptosis. Cell Death Dis. 4:e762. doi: 10.1038/cddis.2013.286

Kaushansky, A., Ye, A. S., Austin, L. S., Mikolajczak, S. A., Vaughan, A. M., Camargo, N., et al. (2013b). Suppression of host p53 is critical for Plasmodium liver-stage infection. Cell Rep. 3, 630-637. doi: 10.1016/j.celrep.2013.02.010

Khan, S. M., Franke-Fayard, B., Mair, G. R., Lasonder, E., Janse, C. J., Mann, M., et al. (2005). Proteome analysis of separated male and female gametocytes reveals novel sex-specific Plasmodium biology. Cell 121, 675-687. doi: 10.1016/j.cell.2005.03.027

Labaied, M., Harupa, A., Dumpit, R. F., Coppens, I., Mikolajczak, S. A., and Kappe, S. H. (2007). Plasmodium yoelii sporozoites with simultaneous deletion of P52 and P36 are completely attenuated and confer sterile immunity against infection. Infect. Immun. 75, 3758-3768. doi: 10.1128/IAI.00225-07

Lasonder, E., Rijpma, S. R., van Schaijk, B. C., Hoeijmakers, W. A., Kensche, P. R., Gresnigt, M. S., et al. (2016). Integrated transcriptomic and proteomic analyses of $P$. falciparum gametocytes: molecular insight into sex-specific processes and translational repression. Nucleic Acids Res. 44, 6087-6101. doi: $10.1093 / \mathrm{nar} / \mathrm{gkw} 536$

Leiriao, P., Albuquerque, S. S., Corso, S., van Gemert, G. J., Sauerwein, R. W., Rodriguez, A., et al. (2005). HGF/MET signalling protects Plasmodium-infected host cells from apoptosis. Cell. Microbiol. 7, 603-609. doi: 10.1111/j.1462-5822.2004.00490.x

Liehl, P., Zuzarte-Luis, V., Chan, J., Zillinger, T., Baptista, F., Carapau, D., et al. (2014). Host-cell sensors for Plasmodium activate innate immunity against liver-stage infection. Nat. Med. 20, 47-53. doi: 10.1038/nm.3424

Lindner, S. E., Mikolajczak, S. A., Vaughan, A. M., Moon, W., Joyce, B. R., Sullivan W. J. Jr., et al. (2013). Perturbations of Plasmodium Puf2 expression and RNA-seq of Puf2-deficient sporozoites reveal a critical role in maintaining RNA homeostasis and parasite transmissibility. Cell. Microbiol. 15, 1266-1283. doi: $10.1111 / \mathrm{cmi} .12116$

Lopes da Silva, M., Thieleke-Matos, C., Cabrita-Santos, L., Ramalho, J. S., WavreShapton, S. T., Futter, C. E., et al. (2012). The host endocytic pathway is essential for Plasmodium berghei late liver stage development. Traffic 13, 1351-1363. doi: 10.1111/j.1600-0854.2012.01398.x

Lu, J., Tong, Y., Pan, J., Yang, Y., Liu, Q., Tan, X., et al. (2016). A redesigned CRISPR/Cas9 system for marker-free genome editing in Plasmodium falciparum. Parasit. Vectors 9:198. doi: 10.1186/s13071-016-1487-4

Mair, G. R., Braks, J. A., Garver, L. S., Wiegant, J. C., Hall, N., Dirks, R. W., et al. (2006). Regulation of sexual development of Plasmodium by translational repression. Science 313, 667-669. doi: 10.1126/science.1125129
Mali, P., Yang, L., Esvelt, K. M., Aach, J., Guell, M., DiCarlo, J. E., et al. (2013). RNA-guided human genome engineering via Cas9. Science 339, 823-826. doi: $10.1126 /$ science. 1232033

Manzoni, G., Marinach, C., Topcu, S., Briquet, S., Grand, M., Tolle, M., et al. (2017). Plasmodium P36 determines host cell receptor usage during sporozoite invasion. Elife 6:e25903. doi: 10.7554/eLife.25903

Matuschewski, K., Ross, J., Brown, S. M., Kaiser, K., Nussenzweig, V., and Kappe, S. H. (2002). Infectivity-associated changes in the transcriptional repertoire of the malaria parasite sporozoite stage. J. Biol. Chem. 277, 41948-41953. doi: 10.1074/jbc.M207315200

Mazumdar, J., Emma, H. W., Masek, K., Hunter, A. C., and Striepen, B. (2006). Apicoplast fatty acid synthesis is essential for organelle biogenesis and parasite survival in Toxoplasma gondii. Proc. Natl. Acad. Sci. U.S.A. 103, 13192-13197. doi: 10.1073/pnas.0603391103

Mellacheruvu, D., Wright, Z., Couzens, A. L., Lambert, J. P., St-Denis, N. A., Li, T., et al. (2013). The CRAPome: a contaminant repository for affinity purificationmass spectrometry data. Nat. Methods 10, 730-736. doi: 10.1038/nmeth.2557

Mikolajczak, S. A., Jacobs-Lorena, V., MacKellar, D. C., Camargo, N., and Kappe, S. H. (2007). L-FABP is a critical host factor for successful malaria liver stage development. Int. J. Parasitol. 37, 483-489. doi: 10.1016/j.ijpara.2007. 01.002

Mikolajczak, S. A., Silva-Rivera, H., Peng, X., Tarun, A. S., Camargo, N., Jacobs-Lorena, V., et al. (2008). Distinct malaria parasite sporozoites reveal transcriptional changes that cause differential tissue infection competence in the mosquito vector and mammalian host. Mol. Cell. Biol. 28, 6196-6207. doi: 10.1128/MCB.00553-08

Miller, J. L., Sack, B. K., Baldwin, M., Vaughan, A. M., and Kappe, S. H. (2014). Interferon-mediated innate immune responses against malaria parasite liver stages. Cell Rep. 7, 436-447. doi: 10.1016/j.celrep.2014.03.018

Miller, L. H., Mason, S. J., Clyde, D. F., and McGinniss, M. H. (1976). The resistance factor to Plasmodium vivax in blacks. The Duffy-blood-group genotype, FyFy. N. Engl. J. Med. 295, 302-304.

Morahan, B. J., Wang, L., and Coppel, R. L. (2009). No TRAP, no invasion. Trends Parasitol. 25, 77-84. doi: 10.1016/j.pt.2008.11.004

Moreira, C. K., Templeton, T. J., Lavazec, C., Hayward, R. E., Hobbs, C. V., Kroeze, H., et al. (2008). The Plasmodium TRAP/MIC2 family member, TRAP-Like Protein (TLP), is involved in tissue traversal by sporozoites. Cell. Microbiol. 10, 1505-1516. doi: 10.1111/j.1462-5822.2008.01143.x

Mota, M. M., Pradel, G., Vanderberg, J. P., Hafalla, J. C., Frevert, U., Nussenzweig, R. S., et al. (2001). Migration of Plasmodium sporozoites through cells before infection. Science 291, 141-144. doi: 10.1126/science.291.5501.141

Mueller, A. K., Camargo, N., Kaiser, K., Andorfer, C., Frevert, U., Matuschewski, K., et al. (2005). Plasmodium liver stage developmental arrest by depletion of a protein at the parasite-host interface. Proc. Natl. Acad. Sci. U.S.A. 102, 3022-3027. doi: 10.1073/pnas.0408442102

Muller, K., Matuschewski, K., and Silvie, O. (2011). The Puf-family RNA-binding protein Puf2 controls sporozoite conversion to liver stages in the malaria parasite. PLoS ONE 6:e19860. doi: 10.1371/journal.pone.0019860

Neafsey, D. E., Juraska, M., Bedford, T., Benkeser, D., Valim, C., Griggs, A., et al. (2015). Genetic diversity and protective efficacy of the RTS,S/AS01 malaria vaccine. N. Engl. J. Med. 373, 2025-2037. doi: 10.1056/NEJMoa1505819

Orito, Y., Ishino, T., Iwanaga, S., Kaneko, I., Kato, T., Menard, R., et al. (2013). Liver-specific protein 2: a Plasmodium protein exported to the hepatocyte cytoplasm and required for merozoite formation. Mol. Microbiol. 87, 66-79. doi: $10.1111 / \mathrm{mmi} .12083$

Pavlopoulos, G. A., Paez-Espino, D., Kyrpides, N. C., and Iliopoulos, I. (2017). Empirical comparison of visualization tools for larger-scale network analysis. Adv. Bioinformatics 2017:1278932. doi: 10.1155/2017/1278932

Pittet, M. J., and Weissleder, R. (2011). Intravital imaging. Cell 147, 983-991. doi: 10.1016/j.cell.2011.11.004

Ploemen, I. H., Croes, H. J., van Gemert, G. J., Wijers-Rouw, M., Hermsen, C. C., and Sauerwein, R. W. (2012). Plasmodium berghei $\Delta p 52 \& p 36$ parasites develop independent of a parasitophorous vacuole membrane in Huh-7 liver cells. PLoS ONE 7:e50772. doi: 10.1371/journal.pone.0050772

Poran, A., Nötzel, C., Aly, O., Mencia-Trinchant, N., Harris, C. T., Guzman, M. L., et al. (2017). Single-Cell RNA sequencing reveals a signature of sexual commitment in malaria parasites. Nature. 551, 95-99. doi: $10.1038 /$ nature 24280 
Prudencio, M., Rodrigues, C. D., Hannus, M., Martin, C., Real, E., Goncalves, L. A., et al. (2008). Kinome-wide RNAi screen implicates at least 5 host hepatocyte kinases in Plasmodium sporozoite infection. PLoS Pathog. 4:e1000201. doi: 10.1371/journal.ppat.1000201

Rodrigues, C. D., Hannus, M., Prudencio, M., Martin, C., Goncalves, L. A., Portugal, S., et al. (2008). Host scavenger receptor SR-BI plays a dual role in the establishment of malaria parasite liver infection. Cell Host Microbe 4, 271-282. doi: 10.1016/j.chom.2008.07.012

Ruivo, M. T., Vera, I. M., Sales-Dias, J., Meireles, P., Gural, N., Bhatia, S. N., et al. (2016). Host AMPK Is a modulator of plasmodium liver infection. Cell Rep. 16, 2539-2545. doi: 10.1016/j.celrep.2016.08.001

Sa, E. C. C., Nyboer, B., Heiss, K., Sanches-Vaz, M., Fontinha, D., Wiedtke, E., et al. (2017). Plasmodium berghei EXP-1 interacts with host Apolipoprotein $\mathrm{H}$ during Plasmodium liver-stage development. Proc. Natl. Acad. Sci. U.S.A. 114, E1138-E1147. doi: 10.1073/pnas.1606419114

Schats, R., Bijker, E. M., van Gemert, G. J., Graumans, W., van de VegteBolmer, M., van Lieshout, L., et al. (2015). Heterologous protection against malaria after immunization with Plasmodium falciparum sporozoites. PLoS ONE 10:e0124243. doi: 10.1371/journal.pone.0124243

Selbach, M., and Mann, M. (2006). Protein interaction screening by quantitative immunoprecipitation combined with knockdown (QUICK). Nat. Methods. 3, 981-983. doi: 10.1038/nmeth972

Shortt, H. E., and Garnham, P. C. (1948). Pre-erythrocytic stage in mammalian malaria parasites. Nature 161:126. doi: 10.1038/161 $126 \mathrm{a} 0$

Silva, P. A., Guerreiro, A., Santos, J. M., Braks, J. A., Janse, C. J., and Mair, G. R. (2016). Translational control of UIS4 protein of the host-parasite interface is mediated by the RNA binding protein Puf 2 in Plasmodium berghei sporozoites. PLoS ONE 11:e0147940. doi: 10.1371/journal.pone.0147940

Silvie, O., Briquet, S., Muller, K., Manzoni, G., and Matuschewski, K. (2014). Post-transcriptional silencing of UIS4 in Plasmodium berghei sporozoites is important for host switch. Mol. Microbiol. 91, 1200-1213. doi: $10.1111 / \mathrm{mmi} .12528$

Silvie, O., Charrin, S., Billard, M., Franetich, J. F., Clark, K. L., van Gemert, G. J., et al. (2006). Cholesterol contributes to the organization of tetraspanin-enriched microdomains and to CD81-dependent infection by malaria sporozoites. J. Cell Sci. 119(Pt 10), 1992-2002. doi: 10.1242/jcs. 02911

Silvie, O., Franetich, J. F., Boucheix, C., Rubinstein, E., and Mazier, D. (2007). Alternative invasion pathways for Plasmodium berghei sporozoites. Int. J. Parasitol. 37, 173-182. doi: 10.1016/j.ijpara.2006.10.005

Silvie, O., Rubinstein, E., Franetich, J. F., Prenant, M., Belnoue, E., Renia, L., et al. (2003). Hepatocyte CD81 is required for Plasmodium falciparum and Plasmodium yoelii sporozoite infectivity. Nat. Med. 9, 93-96. doi: $10.1038 / \mathrm{nm} 808$

Sinha, A., Hughes, K. R., Modrzynska, K. K., Otto, T. D., Pfander, C., Dickens, N. J., et al. (2014). A cascade of DNA-binding proteins for sexual commitment and development in Plasmodium. Nature 507, 253-257. doi: 10.1038/nature12970

Sinturel, F., Gerber, A., Mauvoisin, D., Wang, J., Gatfield, D., Stubblefield, J. J., et al. (2017). Diurnal oscillations in liver mass and cell size accompany ribosome assembly cycles. Cell 169, 651-663.e14. doi: 10.1016/j.cell.2017.04.015

Slavic, K., Delves, M. J., Prudencio, M., Talman, A. M., Straschil, U., Derbyshire, E. T., et al. (2011). Use of a selective inhibitor to define the chemotherapeutic potential of the plasmodial hexose transporter in different stages of the parasite's life cycle. Antimicrob. Agents Chemother. 55, 2824-2830. doi: 10.1128/AAC.01739-10

Stanway, R. R., Graewe, S., Rennenberg, A., Helm, S., and Heussler, V. T. (2009). Highly efficient subcloning of rodent malaria parasites by injection of single merosomes or detached cells. Nat. Protoc. 4, 1433-1439. doi: 10.1038/nprot.2009.172

Sturm, A., Amino, R., C. van de Sand, Regen, T., Retzlaff, S., Rennenberg, A., et al. (2006). Manipulation of host hepatocytes by the malaria parasite for delivery into liver sinusoids. Science 313, 1287-1290. doi: 10.1126/science.11 29720

Tackett, A. J., DeGrasse, J. A., Sekedat, M. D., Oeffinger, M., Rout, M. P., and Chait, B. T. (2005). I-DIRT, a general method for distinguishing between specific and nonspecific protein interactions. J. Proteome Res. 4, 1752-1756. doi: $10.1021 /$ pr050225e
Tarun, A. S., Baer, K., Dumpit, R. F., Gray, S., Lejarcegui, N., Frevert, U., et al. (2006). Quantitative isolation and in vivo imaging of malaria parasite liver stages. Int. J. Parasitol. 36, 1283-1293. doi: 10.1016/j.ijpara.2006.06.009

Tarun, A. S., Peng, X., Dumpit, R. F., Ogata, Y., Silva-Rivera, H., Camargo, N., et al. (2008). A combined transcriptome and proteome survey of malaria parasite liver stages. Proc. Natl. Acad. Sci. U.S.A. 105, 305-310. doi: 10.1073/pnas.0710780104

Tavares, J., Formaglio, P., Thiberge, S., Mordelet, E., Van Rooijen, N., Medvinsky, A., et al. (2013). Role of host cell traversal by the malaria sporozoite during liver infection. J. Exp. Med. 210, 905-915. doi: 10.1084/jem.20121130

Tawk, L., Lacroix, C., Gueirard, P., Kent, R., Gorgette, O., Thiberge, S., et al. (2013). A key role for Plasmodium subtilisin-like SUB1 protease in egress of malaria parasites from host hepatocytes. J. Biol. Chem. 288, 33336-33346. doi: 10.1074/jbc.M113.513234

Trinkle-Mulcahy, L. (2012). Resolving protein interactions and complexes by affinity purification followed by label-based quantitative mass spectrometry. Proteomics 12, 1623-1638. doi: 10.1002/pmic.201100438

Trinkle-Mulcahy, L., Boulon, S., Lam, Y. W., Urcia, R., Boisvert, F. M., Vandermoere, F., et al. (2008). Identifying specific protein interaction partners using quantitative mass spectrometry and bead proteomes. J. Cell Biol. 183, 223-239. doi: $10.1083 /$ jcb.200805092

Usynin, I., Klotz, C., and Frevert, U. (2007). Malaria circumsporozoite protein inhibits the respiratory burst in Kupffer cells. Cell. Microbiol. 9, 2610-2628. doi: 10.1111/j.1462-5822.2007.00982.x

Valacchi, G., Sticozzi, C., Lim, Y., and Pecorelli, A., (2011). Scavenger receptor class B type I: a multifunctional receptor. Ann. N.Y. Acad. Sci. 1229, E1-E7. doi: 10.1111/j.1749-6632.2011.06205.x

van de Sand, C., Horstmann, S., Schmidt, A., Sturm, A., Bolte, S., Krueger, A., et al. (2005). The liver stage of Plasmodium berghei inhibits host cell apoptosis. Mol. Microbiol. 58, 731-742. doi: 10.1111/j.1365-2958.2005.04888.x

van Dijk, M. R., Douradinha, B., Franke-Fayard, B., Heussler, V., van Dooren, M. W., van Schaijk, B., et al. (2005). Genetically attenuated, P36p-deficient malarial sporozoites induce protective immunity and apoptosis of infected liver cells. Proc. Natl. Acad. Sci. U.S.A. 102, 12194-12199. doi: 10.1073/pnas.05009 25102

Van Regenmortel, M. H. (2004). Reductionism and complexity in molecular biology. Scientists now have the tools to unravel biological and overcome the limitations of reductionism. EMBO Rep. 5, 1016-1020. doi: $10.1038 /$ sj.embor.7400284

van Rijnsoever, C., Oorschot, V., and Klumperman, J. (2008). Correlative lightelectron microscopy (CLEM) combining live-cell imaging and immunolabeling of ultrathin cryosections. Nat. Methods 5, 973-980. doi: 10.1038/nmeth.1263

Vaughan, A. M., Mikolajczak, S. A., Wilson, E. M., Grompe, M., Kaushansky, A., Camargo, N., et al. (2012). Complete Plasmodium falciparum liverstage development in liver-chimeric mice. J. Clin. Invest. 122, 3618-3628. doi: 10.1172/JCI62684

Vaughan, A. M., O’Neill, M. T., Tarun, A. S., Camargo, N., Phuong, T. M., Aly, A. S., et al. (2009). Type II fatty acid synthesis is essential only for malaria parasite late liver stage development. Cell. Microbiol. 11, 506-520. doi: 10.1111/j.1462-5822.2008.01270.x

Vaughan, A. M., and Kappe, S. H. I. (2017). Malaria parasite liver infection and exoerythrocytic biology. Cold Spring Harb. Perspect. Med. 7:a025486. doi: 10.1101/cshperspect.a025486

Wagner, J. C., Platt, R. J., Goldfless, S. J., Zhang, F., and Niles, J. C. (2014). Efficient CRISPR-Cas9-mediated genome editing in Plasmodium falciparum. Nat. Methods 11, 915-918. doi: 10.1038/nmeth.3063

WHO (2016). World Malaria Report. Geneva: World Health Organization.

WHO (2017). Overview of Malaria Elimination. Geneva: World Health Organization.

Yalaoui, S., Huby, T., Franetich, J. F., Gego, A., Rametti, A., Moreau, M., et al. (2008a). Scavenger receptor BI boosts hepatocyte permissiveness to Plasmodium infection. Cell Host Microbe 4, 283-292. doi: 10.1016/j.chom.2008.07.013

Yalaoui, S., Zougbede, S., Charrin, S., Silvie, O., Arduise, C., Farhati, K., et al. (2008b). Hepatocyte permissiveness to Plasmodium infection is conveyed by a short and structurally conserved region of the CD81 large extracellular domain. PLoS Pathog. 4:e1000010. doi: 10.1371/journal.ppat.10 00010 
Yang, A. S., O’Neill, M. T., Jennison, C., Lopaticki, S., Allison, C. C., Armistead, J. S., et al. (2017). Cell traversal activity is important for Plasmodium falciparum liver infection in humanized mice. Cell Rep. 18, 3105-3116. doi: 10.1016/j.celrep.2017.03.017

Zhang, M., Fennell, C., Ranford-Cartwright, L., Sakthivel, R., Gueirard, P., Meister, S., et al. (2010). The Plasmodium eukaryotic initiation factor-2alpha kinase IK2 controls the latency of sporozoites in the mosquito salivary glands. J. Exp. Med. 207, 1465-1474. doi: 10.1084/jem.20091975

Zimmerman, P. A., Ferreira, M. U., Howes, R. E., and Mercereau-Puijalon, O. (2013). Red blood cell polymorphism and susceptibility to Plasmodium vivax. Adv Parasitol. 81, 27-76. doi: 10.1016/B978-0-12-407826-0.00002-3
Conflict of Interest Statement: The authors declare that the research was conducted in the absence of any commercial or financial relationships that could be construed as a potential conflict of interest.

Copyright (c) 2017 Zuck, Austin, Danziger, Aitchison and Kaushansky. This is an open-access article distributed under the terms of the Creative Commons Attribution License (CC BY). The use, distribution or reproduction in other forums is permitted, provided the original author(s) or licensor are credited and that the original publication in this journal is cited, in accordance with accepted academic practice. No use, distribution or reproduction is permitted which does not comply with these terms. 